\title{
A medicina no Brasil imperial: fundamentos da autoridade profissional e da legitimidade científica
}

\author{
Flavio Coelho Edler \\ Casa de Oswaldo Cruz, Fiocruz, \\ Río de Janeiro
}

Pretendemos rever la creencia en un supuesto carácter ornamental de las instituciones médicas del Imperio Brasileño (1822-1889). Dichas instituciones estuvieron comprometidas con la producción y la validación de los conocimientos científicos sobre los problemas relativos a la salud pública y privada de los habitantes del imperio. En lugar de las interpretaciones que traducen el pensamiento médico e higienista elaborado por los intereses inmediatos de las élites dominantes —forjando la conciencia médica "desde fuera"-procuraremos subrayar las dinámicas socioprofesionales dirigidas hacia la producción, validación y control del saber médico, según las reglas mismas de la cientificidad adoptadas por la medicina higienista y anatómico-clínica europea, entonces vigentes. El lugar social ocupado por la Academia Imperial de Medicina suponía la existencia de criterios meritocráticos en ese microcosmo. No era la titularidad nobiliaria la que acreditaba la opinión o testigo científico, sino la habilidad de razonar según las reglas científicas consagradas.

Palabras Clave: Historia de la medicina; Brasil, siglo XIX; Climatología y Geografía Médica;

Ciencia, ética, política

This article attempts a fresh analysis of the supposed ornamental nature of medical institutions in Imperial Brazil (1822-1889). The institutions in question were active in the production and validation of scientific knowledge relating to health both public and private in the Empire. In contrast to interpretations which explain medical and hygienic thinking in terms of the immediate interests of dominant elites - forging a medical conscience "from the outside" - the article seeks to highlight the socio-professional dynamics mobilised for the validation and control of medical knowledge according to the same standards of proof prevailing in European hygienic and anatoclinical thought. It is argued that the social position occupied by the Imperial Academy of Medicine was built on meritocratic criteria. It was not the titled nobility which accredited scientific opinion or evidence, but rather the ability to reason in accordance with established scientific standards.

KEYwordS: History of Medicine; Brazil, 19th century; Climatology and Medical Geography; Science, ethics, politics.

\section{Introdução}

A medicina acadêmica imperial, suas instituições, crenças e personagens não gozam de boa reputação entre os historiadores brasileiros. Em geral, os estudos que enfocam um ou outro aspecto da cultura médica ofi- 
cial, ao longo daquele período (1822-1889), tem afirmado que inexistia qualquer prática científica que fundamentasse a atuação dos médicos clínicos ou higienistas. Para a maioria dos autores, foi somente com a institucionalização da medicina pastoriana, na última década do século XIX, que alguns ramos das ciências naturais —nomeadamente a bacteriologia, a entomologia, a helmintologia, a parasitologia macro e microscópica, a fisiologia, e a protozoologia - se tornariam objeto de pesquisas sistemáticas. ${ }^{1}$

Uma vertente interpretativa assevera que a prevalência de uma matriz cultural ibero-americana - reforçada pelo ecletismo espiritualista da filosofia francesa emanada dos cursos jurídicos, e pelo proverbial estilo retórico de nossa intelectualidade - marcaria o compasso da educação superior até pelo menos a década de $1870 .^{2}$ A partir de então, um ideário cientificista empolgaria a intelectualidade oriunda das camadas médias urbanas e ajudaria a enfraquecer a postura anti-científica das elites imperiais, levando à implosão do amálgama de preconceitos difusos que entorpecia a cultura médica brasileira. ${ }^{3}$ Nessa versão, a atividade científica é vista como um conjunto de valores e práticas culturais imanente à sociedade européia moderna, originado durante a chamada Revolução Científica, que teria de ser transplantado e confrontado com os obstáculos antepostos pela cultura tradicional da sociedade brasileira. ${ }^{4}$ No terreno específico da medicina, a versão mais freqüente é a que identifica, como única orientação científica legítima, aquela provinda da prática experimental do laboratório subsidiada pela clínica, o que tem levado muitos historiadores a avaliar as resistências à fisiologia experimental, e à bacteriologia, como resistência à própria ciência, seus métodos e seus valores.

Outros estudiosos admitem, entretanto, que alguns argumentos científicos foram utilizados na formulação de um ideário higienista, desde os primórdios do oitocentos. Mas tais argumentos, copiados ou adaptados de

1 Peard, Julyan. G: "Tropical disorders and the Forging of a Brasilian Medical Identity, 1860-1890", Hispanic American Historical Review, 77: 1 (1997); Santos Filho, Lycurgo de Castro: História Geral da Medicina Brasileira II, EDUSP, São Paulo, 1991; Stepan, Nancy: Gênese e evolução da ciência brasileira: Oswaldo Cruz e a política de investigação científica e médica, Artenova, Rio de Janeiro, 1976.

2 Azevedo, Fernando de: As Ciências no Brasil, São Paulo, 1956; Carvalho, José Murilo de: "História intelectual no Brasil: a retórica como chave de leitura", Rio de Janeiro, Topoi, 1 (2000), págs. 123-152; Schwartzman, Simon: Formação da comunidade científica no Brasil, Nacional, São Paulo, 1979.

3 Luz, Madel T: Medicina e ordem política brasileira, Graal, Rio de Janeiro, 1982.

4 Pires, Denise: Hegemonia médica na saúde e a enfermagem, Cortez, São Paulo, 1989; Schwarcs, Lilia Moritz: O espetáculo das raças, Cia das Letras, São Paulo, 1993. 
compêndios médicos europeus, teriam antes um caráter ideológico. Em conjunto, eles serviriam apenas para legitimar a implantação da ordem burguesa contra os costumes da antiga sociedade patriarcal, ou como justificativa das ações truculentas, direcionadas ao controle e dominação das chamadas "classes perigosas". 5

A suposição de que o saber médico nacional não tinha fundamentação científica, nem era controlado e validado pelos critérios vigentes de cientificidade, levou uma boa parte dos intérpretes da medicina oitocentista a apostarem numa explicação heterônoma de seu processo institucionalização. Se os médicos não tinham uma prática de pesquisa, nem possuíam um critério científico que pudesse servir para balizar suas atividades no campo da terapêutica e da saúde pública, o que decidiria sobre suas ações? Para boa parte dos historiadores que se fizeram esta pergunta, a resposta encontrada soou como um anátema àquele peculiar grupo social que se distinguia pelo uso da bengala com castão de ouro e um anel de esmeralda: eles simplesmente conspiravam a favor dos interesses das elites senhoriais, contra as massas subalternas. A Higiene não passaria de uma ideologia biopolítica de controle social.

Este texto pretende rever tais interpretações, chamando a atenção especificamente para as atividades científicas desempenhadas pelas elites médicas imperiais. Como procuraremos sublinhar, são inúmeras as evidências de que os médicos formados pelas escolas médicas do Rio de Janeiro e de Salvador despenderam grandes esforços no necessário trabalho de inovação científica nos campos do diagnóstico e da terapêutica, na identificação dos agentes deletérios ambientais que se acreditava estarem implicados na produção das doenças próprias ao nosso clima, e na adequação das medidas profiláticas propugnadas pela Higiene às condições nacionais. E fizeram-no não apenas institucionalizando a pesquisa anatomoclínica e higienista, mas também assimilando seletivamente alguns ramos das ciências naturais —a Botânica, a Meteorologia, a Climatologia, a Geologia, a Topografia - de cujo conhecimento eles dependiam para levar a cabo a agenda de pesquisas sobre a patologia brasileira proposta inicialmente pelo grupo que criou a Academia Imperial de Medicina, em 1829.

A essa altura o leitor já deve estar pensando que partilhamos do ponto de vista do alienista Simão Bacamarte, famoso personagem do roman-

5 Chalhoub, Sidney: Cidade Febril. Cortiços e epidemias na corte imperial, Cia da Letras, São Paulo, 1996; Costa, Jurandir Freire: Ordem médica e norma familiar, Graal, Rio de Janeiro, 1980; Costa, Nilson do Rosário: Lutas urbanas e controle sanitário, Vozes, Petrópolis, 1985; Machado, Roberto: Danação da Norma, Graal, Rio de Janeiro, 1978. 
cista Machado de Assis, para quem "homem de ciência é só de ciência, nada o consterna fora da ciência". Não se trata disso. De fato, a Higiene forneceu a sintaxe que permitiria apreender e pensar, em termos científicos e ideológicos, os inúmeros conflitos étnicos, políticos e sociais, ligados à lógica de organização senhorial do espaço urbano. O que rejeitamos é a crença generalizada no caráter supostamente ornamental de instituições médicas, como as faculdades de Medicina do Rio de Janeiro e Bahia, a Academia Imperial de Medicina e dezenas de periódicos médicos publicados em diversas províncias. Tais instituições estiveram implicadas na produção, revisão e validação dos conhecimentos científicos sobre a vasta constelação de problemas relacionados à saúde pública e privada dos habitantes do império. Assim, no lugar das interpretações que explicam o pensamento médico e higienista deduzindo-o dos interesses imediatos das elites dominantes - forjando a consciência médica "de fora"- procuraremos sublinhar as dinâmicas sócio-profissionais voltadas para produzir, validar e controlar o saber médico, segundo as mesmas regras de cientificidade abraçadas pela medicina higienista e anatomoclínica européia então vigentes.

Podemos formular nosso argumento nos seguintes termos: ao compartilharem com os colegas europeus uma noção de doença inextricavelmente ligada ao meio ambiente, clínicos e higienistas brasileiros do Império admitiam uma concepção particularista, em termos territoriais e climáticotelúricos, do conhecimento médico. Contraditoriamente, essa particularidade do saber médico local baseava-se no pressuposto da universalidade dos princípios da Anatomia, da Química, da Física, da Fisiologia, além das ciências naturais acima referidas. Tal saber, fundado numa patologia ambientalista, aparecia como inscrito na natureza das coisas, isto é, como o limite imposto de qualquer reflexão sobre etiologia ou patogenia. Era com base na detenção especial desse saber abstrato aprendido no período de formação profissional que esse grupo social pleiteava uma jurisdição formal e exclusiva sobre a formação e o exercício da medicina em bases territoriais, confrontando-se tanto com o saber médico gerado em outras regiões, como com outras categorias de curadores a que denominariam charlatões.

Naquele período a produção e o controle de conhecimentos sobre diagnóstico, terapêutica, profilaxia ou etiologia das doenças seguia formas estritas de controle profissional. O que credenciava uma opinião ou testemunho era a habilidade em atuar de acordo com os protocolos científicos em vigor, isto é, conforme certas regras de "etiqueta científica". Essas 
regras, definidas inicialmente no âmbito da Anatomoclínica e da Higiene, tinham como suporte uma ontologia meteoropatológica e uma epistemologia sensualista. Foi em torno dessas regras que se desenvolveu grande parte das controvérsias científicas até o momento em que a medicina experimental, especialmente a parasitologia macro e microscópica vieram desestabilizá-las ao propor outros cânones científicos.

Ao contrário do que veio a se afirmar já a partir da década de 1880 - quando o olhar retrospectivo da geração de médicos pastorianos passou a desdenhar a Climatologia Médica como conhecimento vulgar- a relação homem-doença-clima, admitida até então, era uma equação muito sofisticada do ponto de vista do debate metodológico e às controvérsias científicas da época não faltava base empírica e meticulosa observação. ${ }^{6}$ A partir de meados daquele século, com a maior precisão que a estatística médica emprestou aos trabalhos de topografia médica, e com a disseminação do protocolo anatomoclínico por todo o globo terrestre, ${ }^{7}$ cada um daqueles termos perderia estabilidade semântica. Por um lado, poligenistas e monogenistas discordavam sobre a unidade da espécie humana, mas mesmos entre os monogenistas variava boa parte dos atributos que se imputava às raças. Por outro, a etiologia das doenças endêmicas e epidêmicas tornou-se objeto de infindáveis querelas no campo da climatologia médica. E mesmo a noção de clima tropical, como configuração meteorológica estável e válida para a imensa região do globo compreendida entre os trópicos, foi sendo paulatinamente redefinida. E os médicos brasileiros contribuíram decisivamente no desenrolar desses debates. ${ }^{8}$

\section{Topografia Médica e ciências naturais no período pós-iluminista}

A partir de fins do século XVIII, o gênero de literatura científica conhecido como Topografia Médica renovou os estudos que correlacionavam os aspectos ambientais que, numa certa localidade, eram tomados como

6 Lawrence, Christopher: "Incommunicable knowledge: Science technology and clinical art in Britain 1850-1814”, Journal of Contemporary History, SAGE, London, Vol. 20 (1985), págs. 503-20.

7 Warner, John Harley: "The fall and rise of professional mystery. Epistemology, authority and the emergence of laboratory medicine in nineteenth-century America", en Cunningham, A. \& Willams, P (Coords): The laboratory revolution in medicine, Cambridge University Press, Cambridge, 1992, págs. 110-141.

8 Edler, Flavio Coelho. A constituição da Medicina Tropical no Brasil oitocentista: da climatologia à parasitologia médica, Tese de Doutorado, IMS-Uerj, Rio de Janeiro, 1999. 
protagonistas na produção de certas doenças. Nesse período, uma série de novos instrumentos de medição dos fatores meteorológicos estava sendo desenvolvida, tal como o termômetro, o barômetro, o pluviômetro, aparelhos para a medição da velocidade dos ventos e da composição química do ar atmosférico —o eudiômetro. Com isto, surgiu a possibilidade de uma meteorologia quantificada no lugar das descrições qualitativas até então prevalecentes. ${ }^{9}$ A síntese entre as ciências ambientais —a climatologia, a meteorologia, a topografia e a geologia- e a medicina, então profundamente influenciada pela démarche sensualista, tinha raízes profundas na filosofia natural do século das luzes. A literatura sobre as causas ambientais das doenças mantinha uma orientação empirista. Naturalistas, médicos de província e membros correspondentes de sociedades científicas eram incentivados a reunir um volume crescente de dados climatológicos e nosológicos, visando à produção de séries diárias de observações meteorológicas correlacionadas com a estatística de certas doenças. Lécuyer salienta que o protocolo de observações, implementado pela climatologia médica, partia das circunstâncias mais gerais até alcançar aquelas particulares ao doente. O bom médico examinava, então, sucessivamente os circunfusa (meteorologia, hidrologia, geologia, climas e habitações), os ingesta (alimentos e bebidas), os excreta (excreções e banhos), os applicata (vestimentas e cosméticos), os percepta (costumes, sexualidade, higiene pessoal) e, por fim, os gesta (movimentos habituais, atividades profissionais). ${ }^{10}$

Nos compêndios de patologia aprendia-se uma noção não essencialista das doenças, que não teriam uma existência em si, ainda que os autores a elas se referissem como entidades distintas quase sempre localizadas espacialmente nas partes sólidas do corpo. ${ }^{11}$ A natureza de uma doença manteria referência direta com o temperamento e a estrutura peculiar de um indivíduo — sua constituição física - seu dinamismo fisiológico e psicológico. Assim, os agentes externos — miasma, calor, pressão atmosférica, umidade, parasitas, temperatura, gases químicos- jamais concorreriam isoladamente para formar uma afecção. Eles poderiam contribuir — circunstancialmente, ou de modo preponderante - para produzir uma situa-

9 Hannaway, Caroline: "Environment and Miasmata" en Bynum, W. F. \& Porter, Roy (Coords): Companion Encyclopedia of the History of Medicine, Routledge, London, 1993. págs. 292-308.

10 Lécuyer, Bernard P: "L' Hygiène en France avant Pasteur", en Claire Salomon-Bayet (Coord) Pasteur et la Révolution Pastorienne, Payot, Paris, 1986, págs. 65-139.

11 Canguilhem, G: Ideologia e Racionalidade nas Ciências da Vida, Edições 70, Lisboa, 1977. 
ção que, eventualmente, conduziria a um estado mórbido. Seriam uma condição necessária, mas nunca suficiente. No limite, cada paciente possuiria uma identidade fisiológica particular. Um médico que conhecesse as idiossincrasias próprias à constituição física de seu paciente ou de sua família ou que praticasse normalmente em certo meio ambiente, estaria em melhor posição para identificar e curar uma afecção que um médico estranho à família ou ao lugar. ${ }^{12}$ Como o diagnóstico e a terapêutica eram tipos de saberes contingentes - dependentes das mutáveis circunstâncias climáticotelúricas- as instituições voltadas à produção, formação e aplicação do conhecimento médico - jornais, faculdades, academias - teriam sua jurisdição inextricavelmente circunscrita a um meio ambiente.

A Higiene colonial ou metropolitana, amparando-se nos estudos de Topografia Médica, tinha como projeto não apenas estabelecer os limites geográficos das doenças e a duração das epidemias, mas também esclarecer sobre a influência das condições meteorológicas e seu modo de propagação e disseminação. Entretanto, até meados daquele século, os elementos climáticos eram tomados de um modo tal que era sempre impossível dissociá-los na prática. Assim, os componentes do ar atuariam diferentemente se o ar estivesse calmo ou agitado, seco ou úmido; o campo elétrico e o estado da ozona difeririam segundo outras condições meteorológicas. Os efeitos do calor dependeriam largamente do grau de umidade; os ventos teriam sua ação regulada pela temperatura. Toda variação de um só elemento seria acompanhada de uma modificação em todos os outros.

\section{Como se produzia e validava o conhecimento médico?}

Entre fins do século XVIII e inícios do século XIX, a medicina hospitalar francesa implantaria um novo programa de pesquisa médica, caracterizada pela prioridade epistemológica do discurso empirista. De acordo com a retórica sensualista tomada de empréstimo aos idéologues, o "novo" doutor seria um detetive rasteando incansavelmente a doença, por meio do

12 Hamlin, C: "Predisposing causes and public health in early nineteenth-century medical thought", Social History of Medicine 5 (1992), págs. 43-70; Rosenberg, Charles E.: " The Therapeutic Revolution: Medicine, Meaning and Social Change in 19th - Century America" en Leavitt, Judith Walzer \& Numbers, Ronald L. (Coords): Sickness and Health in America, The University of Wisconsin Press, Wisconsin, 1985, págs. 39-51.

13 Porter, Roy: The Greatest benefit to mankind. A medical History of humanity from antiquity to the present, Harper Collins Publishers, London, 1997. 
instrumental investigativo forjado pela Anatomoclínica. ${ }^{13} \mathrm{O}$ hospital tornarse-ia um centro do ensino e pesquisa, além de árbitro do conhecimento médico. No domínio do conhecimento médico, a patologia humoral foi substituída pela anatomopatologia, que identificaria as doenças com lesões orgânicas. A partir de então, como vimos, um relatório clínico seria caracteristicamente composto de uma série de detalhadas narrativas que incluíam informações sobre a sintomatologia do paciente e sobre o meio ambiente físico e social. Nesse sentido estrito de um conjunto de procedimentos e técnicas de diagnóstico —exame físico, percussão mediata, estetoscópio, autópsia, patologia tissular - a Anatomoclínica tornou-se a primeira tradição médica verdadeiramente internacional. ${ }^{14}$

O exame clínico, ou anamnesis, passou a ser visto como o primeiro passo para a construção de um conhecimento médico científico; ele se associava aos pressupostos da indução científica e era percebido como uma alternativa à especulação teórica e à experimentação..$^{15}$ Como notou Rosen, a retórica empirista que pretendia extrair o conhecimento verdadeiro através da observação e análise direta da natureza, também incorporava uma intenção política pós-revolucionária de setores da medicina francesa. Tais grupos aspiravam representar uma reação contra o racionalismo iluminista dos sistemas patológicos especulativos atribuídos à medicina do Antigo Regime. ${ }^{16}$ Largamente percebida como a essência da ciência clínica, a idéia de observação ligava-se a uma aplicação rigorosa dos sentidos - a única fonte de conhecimento legítimo- aos objetos da medicina. Partindo da estreita observação dos efeitos de um tratamento em um paciente com sintomas particulares, vivendo num determinado meio ambiente, com hábitos e constituição física singulares, os médicos poderiam derivar prescrições terapêuticas válidas em condições similares. Raciocinando sobre muitos casos semelhantes, os clínicos poderiam tirar conclusões genéricas sobre doenças e terapêuticas. Se tais preceitos poderiam, ou não, ser transportados para outras condições, era algo a ser averiguado. As faculdades de medicina, sociedades e jornais médicos, seriam fóruns institucionais investidos da tarefa de construir e certificar o corpo

14 Maulitz, Russel C: "Physician versus bacteriologist: The ideology of science in clinical Medicine", en Vogel Morris J. \& Rosenberg, Charles E (Coords): The therapeutic Revolution, University of Pennsylvania Press, Pennsylvania, 1979, págs. 91-107.

15 Weisz, George: The Medical Mandarins. The French Academy of Medicine in the Nineteenth and Early Twentieth centuries, Oxford University Press, New York, 1995.

16 Rosen, George "The philosophy of ideology and the emergence of modern medicine in France”, Bulletin of the History of Medicine, Vol. 20 (1946), págs. 328-39. 
de conhecimentos médicos dentro desses limites regionais impostos pela epistemologia clínica. ${ }^{17}$

Não pretendemos tomar o discurso empirista como um espelho fiel da prática médica de então. Para nós, trata-se de uma representação ideal dessa prática. Tal representação possuía uma dimensão normativa, crucial para entendermos como se construía o sistema de autoridade e competência científica. Se a base do sistema era a prática hospitalar, seu ápice, formado pelas sociedades médicas, teria que espelhar ou traduzir essa prática. Podemos tomar a nomenclatura epistemológica empirista como ponto de partida para uma apresentação formal de tal sistema de poder profissional, que compreendia redes regionais, nacionais e internacionais, na disputa pelo privilégio de controle e validação dos conhecimentos médicos: a distinção entre fatos e hipóteses traduzia a idéia de que aqueles seriam fruto de costumeiras, repetidas e consensuais observações coletivas. Já as hipóteses, correspondiam a observações raras ou induções pouco consensuais relativamente ao fórum institucional que as apreciava. Assim, o que era "fato científico" para clínicos de uma localidade, ou membros de uma subespecialidade médica, poderia ser tomado como "hipótese" em contextos sócio-profissionais distintos. A hierarquização axiológica entre fatos e hipóteses teria como tradução sociológica uma similar hierarquização entre as coletividades médicas e suas instituições.

Como notou Weisz, o termo observation, estando na base, era também o calcanhar de Aquiles do processo de construção e validação do conhecimento médico. Contrastando com a Química ou a Física de seu tempo, a Anatomoclínica e a Topografia Médica trabalhavam com uma versão mais rudimentar de verdade, associada à reconhecida precariedade da epistemologia indutivista. Os defensores da aplicação do método estatístico para dirimir controvérsias relativas à prática médica pretendiam que ele traria mais rigor e exatidão à indução lógica das observações clínicas. Entretanto, somente na segunda metade do século XIX a estatística começaria a ser admitida mais amplamente, tendo um papel significativo nos debates médicos. Essa medicina de gabinete era praticada por médicos que, além de sua clínica privada, eram ou almejavam se tornar administradores burocratas. ${ }^{18}$ Embora os defensores da aplicação da estatística à higiene tivessem as mesmas referências filosóficas sensualistas que os clínicos, esses últimos

17 Warner, John Harley: "The fall and rise of professional mystery...”, págs. 120-24.

18 Porter, Theodore M: The rise of statistical thinking, Princeton University Press, Princeton, 1986. 
desconfiavam de um método que tendia a ultrapassar, pela generalização, os limites sancionados pela prática coletiva. $\mathrm{O}$ conhecimento sobre a patologia própria a cada região, patrimônio dos médicos que aí praticavam, era controlado pelas sociedades médicas. Estas zelavam pela preservação desse conhecimento local, velando pela memória dessa experiência comum.

A aplicação do método estatístico vinha subverter o processo tradicional de validação do conhecimento médico, pois o emprego das médias matemáticas substituía a discussão do caso clínico concreto e a autoridade da experiência clínica hospitalar se anulava diante do argumento estatístico produzido num gabinete de uma repartição burocrática. $\mathrm{O}$ mesmo fenômeno se daria, em seguida, quando os adeptos da fisiologia experimental pretenderam deslocar o espaço de produção de conhecimento médico do hospital para o laboratório, substituindo o leito pela bancada. ${ }^{19}$

\section{A produção científica da medicina acadêmica brasileira}

A organização profissional e regulamentação da educação médica no Brasil, como atividade diversa da praticada por barbeiros, sangradores, práticos e curandeiros, começou apenas no século XIX, motivada pela súbita fuga da Corte portuguesa, ameaçada pelas tropas de Junot, para a cidade do Rio de Janeiro. Nessa ocasião, o Príncipe Regente D. João VI, iniciava uma série de reformas de cunho liberal, criando também os primeiros estabelecimentos de caráter cultural. No tocante à medicina, criou dois cursos de cirurgia e anatomia nos hospitais militares de Salvador e Rio de Janeiro (1808), pondo término à era dos físicos e cirurgiões formados exclusivamente na Europa. Iniciava-se, assim, uma forte tradição clínica marcada pela figura do médico-de-família que atuava, ora como clínico, ora como cirurgião, ora como conselheiro higienista. Em 1832, as Academias Médico-Cirúrgicas foram transformadas em Faculdades de Medicina do Rio de Janeiro e da Bahia. O mesmo decreto instituía os cursos de Medicina, Farmácia e de Partos. O figurino das novas faculdades seguia o modelo francês, conforme orientação da Sociedade de Medicina do Rio de Janeiro (1829-1835) —embrião da Academia Imperial de Medicina.

Quando a Sociedade de Medicina foi criada, a Higiene e a Anatomoclínica passaram a dispor de uma trincheira estrategicamente

19 Löwy, Ilana: "Recent historiography of biomedical research", en Ghislaine Lawrence (Coord.): Technologies of Modern Medicine, Science Museum, London, 1994, págs. 99-110. 
orientada para enfraquecer a influência dos antigos cirurgiões portugueses e daqueles formados nas escolas Médico-Cirúrgicas da Corte e da Bahia. ${ }^{20}$ Nesse contexto, a Anatomoclínica era praticamente toda a medicina, já que a Fisiologia Experimental de Claude Bernard (1813-1878) e a Patologia Celular de Rudolph Virchow (1821-1902), que viriam a produzir uma medicina de laboratório —-medicina sem doentes-, estavam apenas se esboçando no horizonte da clínica. Nesse período, marcado pela crença da dependência da patologia e da terapêutica médicas aos fatores climáticotelúricos circunscritos ao meio ambiente, a rejeição da herança colonial da Fisicatura-mor e do legado de informações médicas, mais ou menos impressionistas, descritas pelos viajantes naturalistas, impôs-se como précondição à afirmação do novo ethos profissional.

Em torno da Academia de Medicina, uma elite médica empenhou-se, aguerridamente, na produção de um conhecimento original sobre a patologia brasileira. Desde sua criação, até meados do século, ela conseguiria monopolizar duas importantes tarefas: ao mesmo tempo que se impusera como instrumento da política imperial da saúde pública, tornara-se o principal árbitro das inovações médico-científicas, contribuindo tanto para sancionar novas tecnologias em diagnóstico e terapêutica quanto novos conceitos e teorias estritamente voltados para o conhecimento da patologia brasileira. Tal como a Academia de Medicina de Paris, que lhe servira como figurino, ela oferecia prêmios em competições anuais, coletava e examinava informações epidemiológicas, administrava a vacinação anti-variólica, auxiliando o governo em matéria de educação médica, polícia higienista e saúde pública. A comparação entre as duas pode ser estendida a alguns de seus êxitos e fracassos: nas duas instituições, a produção, coordenação e arbitragem de um conhecimento médico orientado para a saúde pública resultou na organização da profissão médica — bem mais precária no caso brasileiro - visando constituir uma rede de informações e coletas, cujo conjunto deveria ser processado, analisado e eventualmente aplicado pelos acadêmicos. Consolidavam-se, desse modo, as desigualdades regionais em benefício das elites médicas da capital, beneficiárias diretas de sua proximidade com as fontes de poder estatal; ambas, por outro lado, sairiam igualmente derrotadas em suas pretensões de centralizar em suas mãos o poder de polícia no campo da saúde.

20 Ferreira, Luis Otávio: O Nascimento de uma instituição científica: os periódicos médicos brasileiros da primeira metade do século XIX, tese de doutorado, FFLCH-USP, São Paulo, 1996. 
Um corpo de modestos peritos seria útil ao governo, enquanto outro, com excessivas pretensões administrativas, poderia se tornar um embaraço político. Os acadêmicos, aqui e lá, queriam poderes administrativos, mas só obtiveram um papel consultivo. A criação de uma Junta Central de Higiene Pública, em 1850, não representou o ápice do poder político dos higienistas brasileiros, como querem alguns historiadores. Além de esvaziar o poder da Academia de Medicina, a criação daquele órgão subordinou as ações oficiais no campo da saúde pública e polícia médica à pauta política e administrativa mais geral, o que gerou queixas e lamúrias por parte de acadêmicos e da imprensa médica independente, na Corte e na Bahia, ${ }^{21}$ que ecoaram até as reformas do ensino médico e da legislação sanitária, na década de 1880.

Nos trabalhos dos acadêmicos, publicados no Propagador das Sciências Médicas, no Diário de Saúde, no Semanário de Saúde Publica e na Revista Médica Fluminense —os dois últimos, órgãos da Academia Imperial de Medicina - destacava-se, como morbidade dominante da patologia nacional, a febre palustre. Essa convicção era fundada cientificamente, segundo as regras de produção de fatos e teorias compartilhadas no contexto da experiência sócio-cognitiva da medicina anatomoclínica e do paradigma climatológico, que descrevemos acima. Tal epistemologia pressupunha a existência de instituições, como a Academia de Medicina, que regulavam uma prática coletiva, territorialmente delimitada, na coleta de registros de observações clínicas que compreendiam a descrição de diagnósticos, etiologias e terapêuticas utilizadas, e do exame anatomopatológico pós-morte. Tal regime de produção de fatos médico-científicos pressupunha o compromisso da corporação médica local na produção de um conhecimento necessariamente restrito à sua própria jurisdição ambiental.

Outras endemias constatadas por aquele corpo de profissionais seriam o reumatismo, a erisipela, o piã, a hidrocele, a lepra, as hemorróidas, a hipoemia intertropical, a elefantíase dos árabes, a hemato-chyluria. Ao lado dessas endemias, algumas epidemias tinham orientado os debates nas suas sessões semanais: a gripe, a sífilis, as bexigas, as doenças do fígado, do coração e da pele, o sarampo, a escarlatina, as febres tifóides, o tétano e o

21 Sobre a Academia de Medicina francesa, ver Weisz, George: The Medical Mandarins..., 1995. Sobre a Academia Imperial de Medicina, ver Edler, Flavio Coelho: As Reformas do Ensino Médico e a Profissionalização da Medicina na Corte do Rio de Janeiro 1854-1884. Tese de mestrado, FFLCH-USP, São Paulo, 1992; Kury, Lorelai Brilhante: O Império dos miasmas: A Academia Imperial de Medicina (1830-1850), Dissertação de mestrado, Pós-graduação em História Universidade Federal Fluminense, Niterói, 1991. 
escorbuto. A avaliação dos acadêmicos, na primeira metade do oitocentos, era a de que o país ostentava uma boa condição de salubridade.

Querendo impor o monopólio da interlocução sobre os problemas médicos nacionais diante do Governo Imperial e dos centros médico-científicos europeus, a Academia de Medicina esforçou-se por cumprir a tarefa de traduzir e atualizar a pauta higienista e anatomoclínica européia contemporânea, o que a tornaria intérprete legítima da patologia brasileira. Diante das questões consagradas pela Geografia Médica, ${ }^{22}$ os médicos brasileiros apresentaram respostas originais, algumas das quais se opunham a velhos estigmas raciológicos veiculados em compêndios médicos europeus. Além disso produziram uma avaliação positiva a respeito da patologia nacional, onde não teriam direito de domicílio algumas das mais temidas enfermidades, como a febre amarela, a peste e o cólera.

Algumas dessas soluções originais foram coligidas por um dos fundadores da Academia de Medicina, o médico francês Xavier Sigaud. ${ }^{23}$ Os acadêmicos imputavam ao calor e à umidade um papel preponderante, dentre os fatores climático-telúricos na patologia nacional, descrevendo sua ação direta (patogenia) ou indireta (miasmas) na economia humana e formas profiláticas para se evitar sua ação deletéria. Entretanto de acordo com o consenso médico de então, na composição dos estados mórbidos, os fatores morbígenos decisivos seriam ligados aos hábitos higiênicos. Assim, os "primeiros agentes da mortalidade" no Brasil, seriam o "regime alimentar" e o abuso do "ato venéreo". Uma postura saudável centrada na exclusão dessas causas predisponentes redundaria numa atenuação dos efeitos das principais causas climáticas excitantes: o calor, a umidade e os miasmas. ${ }^{24}$ Os acadêmicos também apresentaram uma avaliação generosa sobre o problema da aclimatação, ligada conjunturalmente à grave questão da imigração européia, apontada por eminências políticas como a solução alternativa ao fim do tráfico negreiro imposto pela Inglaterra. E fizeram-no, condenando certos costumes europeus importados indiscriminadamente.

A apresentação de um receituário higiênico adaptado às novas condições climáticas, voltado a um ajuste saudável, deve ser interpretado como um trunfo a ser creditado aos médicos nacionais, em seu esforço de revisão

22 A Geografia Médica era uma disciplina que pretendia conter o conhecimento patológico em escala global. Seus mais influentes representantes eram médicos europeus, geralmente ligados às administrações coloniais.

23 Sigaud, J. -F. X: Du Climat et des Maladies du Brésil ou Statistique Médicale de cet Empire, Chez Fortin, Masson et Cie, Libraires, Paris, 1844.

24 Ibídem, pág. 59. 
dos tratados europeus de Patologia e Higiene, e criação de uma cultura médica local. Desse modo, tanto o trabalho de revisão teórica, ligado ao rebaixamento do papel dos agentes meteorológicos e dos temperamentos na hierarquia da produção de doenças, em benefício dos hábitos, quanto a interpelação desses mesmos hábitos seculares, tais como os "banhos frios", as "bebidas alcoólicas", o "uso do leite", a "tendência de se seguir a moda de Paris ou de Londres, contrária à sã higiene", espelhariam o esforço de conformação da cultura médica nacional aos ditames impostos pela singular patologia brasileira. ${ }^{25}$

Mencionaremos, por fim, um último exemplo de originalidade dos médicos brasileiros da primeira metade do oitocentos diante de crenças científicas consagradas pela medicina européia. Contrariando a opinião de alguns confrades europeus, que atribuiriam à "mistura das raças" a produção de novas doenças inexistentes na patologia européia, a Academia de Medicina asseverava que "as doenças que cada uma das raças trouxe ao pais não teria degenerado pela transmissão às outras raças" (...) "O piã, importado da África, a sífilis dos indígenas e a varíola da Europa" seriam idênticas ao que eram três séculos antes. Apenas à "natureza das localidades" e ao "regime das populações" poderia ser imputado "o segredo patológico do país" ${ }^{26}$ Lembremos, porém, que boa parte dessas crenças científicas não era consensual, sendo objeto de renhidas disputas entre os acadêmicos.

Embora polêmica em alguns pontos, a descrição da carta nosográfica do Império consistiu num trunfo espetacular da Academia Imperial de Medicina que, ao aclimatar o conhecimento médico europeu a partir de um núcleo de disciplinas médicas universais às condições climático-telúricas brasileiras, tornou-se sua fiadora e controladora, praticamente monopolizando a interlocução com as instituições médicas centrais até meados do século XIX.

Entretanto, três acontecimentos iriam por em risco o lugar social que a Academia Imperial de Medicina conquistara ainda em seu primeiro quarto de século de existência. Primeiramente, a inesperada irrupção de duas das mais temidas epidemias conhecidas: a capital do Império e outras importantes cidades litorâneas foram acometidas de surtos de febre amarela (1849) e cólera (1855). A febre amarela, cuja última aparição ocorrera no século XVII, se transformaria em curto espaço de tempo na principal 
questão de saúde pública no Brasil. ${ }^{27}$ Tal fato, decisivo na mudança do perfil de salubridade descrito por Sigaud, também contribuiu para a criação da Junta Central de Higiene Pública —o segundo evento- que deslocaria a Academia do papel central que até então representara para a saúde pública. A Junta permitiu conter as pretensões administrativas da Academia, tornando-se subserviente às diretrizes governamentais no período de maior centralização política do Império, que se seguiu à curta experiência liberal das regências (1831-1840). O terceiro acontecimento se refere ao deslocamento epistemológico operado pela medicina experimental, que resultou no aparecimento de sociedades e periódicos médicos concorrentes, a partir da década de 1860. Estes novos circuitos de legitimação científica iriam romper com o monopólio até então desfrutado pelos periódicos médicos oficiais da Academia de Medicina. Na Bahia e no Rio de Janeiro, o periodismo médico permitiria o incremento do intercâmbio científico e a consolidação de uma pauta de pesquisas voltada principalmente ao conhecimento da matéria médica (fitoterapia), patologia e terapêutica nacionais estimulando e dirigindo as incipientes iniciativas individuais de pesquisa médica, e criando condições para a legitimação dos novos ramos disciplinares reivindicados pelos reformadores do ensino médico. Além da Gazeta Médica da Bahia (1866-1915) podemos considerar como relevantes no trabalho de emulação científica, segundo os moldes da época, os seguintes periódicos da Corte: a Gazeta Médica do Rio de Janeiro (1862-1864); a Revista Médica do Rio de Janeiro (1873-1879); os Archivos de Medicina (1874); o Progresso Médico (1876-1880); a União Médica (1881-1889); a Gazeta Médica Brazileira (1882) e o Brazil Médico (1887-1964).

A partir da década de 1870 ocorreria uma inflexão no programa de pesquisa médica agora capitaneado pelos periódicos acima referidos. As novas elites profissionais passaram a perseguir pari passu o movimento de reforma institucional que, sob o impacto das dinâmicas de pesquisas experimentais, subvertiam a hierarquia médica encimada pela Clínica e pela Higiene. A emergência das disciplinas que cabiam no rótulo de Medicina Experimental e as novas especialidades clínicas tornaram imperativa uma reforma curricular que contemplasse a redefinição e ampliação do antigo estoque de conhecimento. Convulsionado pela demanda por novos profissionais especialistas, o território acadêmico assistiria à fragmentação das

27 Sobre a febre amarela no Brasil, ver o trabalho de Benchimol, Jaime Larry: Do Pasteur dos micróbios ao Pasteur dos Mosquitos: febre amarela no Rio de Janeiro (1880-1903), Tese de doutoramento (Curso de Pós Graduação em História) Universidade Federal Fluminense, Niterói, 1996. 
antigas fronteiras jurisdicionais. Contudo, admitia-se que o saber a ser aplicado por médicos legistas, investigadores de Matéria Médica, toxicologistas, fisiologistas, patologistas, higienistas com sólida formação em estatística, além das novas especialidades clínicas — relacionadas com novos objetos como patologias específicas, áreas limitadas do organismo humano e determinadas faixas etárias - teria que ser adaptado aos problemas médicos nacionais. Como conclamou um dos líderes do vitorioso movimento por reformas do ensino médico, na década de 1880: "temos necessidade, fazendo aplicações dos meios experimentais, das luzes que recebemos com o desenvolvimento da arte, de estudar os males que nos afligem, segundo as modificações que lhes imprimem não só a topografia, como as influências climatéricas, os nossos usos e a índole especial de nossa raça". ${ }^{28}$

O grande consenso empirista no período em que Torres-Homem (1839-1887), lente de Clínica, pontificava sobre seus pares, não era impermeável à crítica metódica, posto que não estava alheio às dificuldades que se impunham à observação e apreciação dos fatos. Fatos mal observados ou falsas relações causais apenas supostas pela sucessão de eventos haviam levado à ruína as mais sólidas teorias. O post hoc ergo propter hoc, risco epistemológico denunciado por todos, pairava como uma ameaça às mais consensuais teorias. A adesão à epistemologia sensualista implicou num compromisso com uma versão de verdade muito mais precária. As elites médicas imperiais sabiam disso. Por isso mesmo, as diferentes representações expressas pelos emblemas broussaísta, eclético, humoralista, organicista, contagionista, anti-contagionista, atribuídas a grupos médicos naquele período, não representavam necessariamente rupturas, mas cristalizações de posições congruentes com o consenso primordial da anatomoclínica. Apenas com a emergência das pesquisas parasitológicas e bacteriológicas se iniciaria o processo que levaria, ao cabo de renhidas lutas, à construção de uma nova ortodoxia paradigmática no alvorecer do período republicano. Claro está que para a medicina pastoriana que faria triunfar, em fins do século XIX, a tese da etiologia específica, revogando toda a legitimidade da démarche climático-telúrica, tal programa de pesquisa nada tinha de científico. A passagem desses fatos científicos à categoria de crendices ou de mitos, em fins do século XIX, correspondeu a uma alteração das regras de produção de verdades, isto é, à mudança do status de certas práticas e dos grupos que as sustentavam bem como a uma redefinição das hierar-

28 Afirmação do parasitologista Julio de Moura (1839-1892) na década de 1870, Apud Edler, Flavio Coelho: As Reformas do Ensino Médico..., pág. 87. 
quias e valores sócio-profissionais. Claro está que para a medicina pastoriana que faria triunfar, em fins do século XIX, a tese da etiologia específica, revogando toda a legitimidade da démarche climático-telúrica, tal programa de pesquisa nada tinha de científico. A passagem desses fatos científicos à categoria de crendices ou de mitos, em fins do século XIX, correspondeu a uma alteração das regras de produção de verdades, isto é, à mudança do status de certas práticas e dos grupos que as sustentavam bem como a uma redefinição das hierarquias e valores sócio-profissionais.

\section{Conclusão}

Como vimos, o universo médico brasileiro, no contexto da institucionalização dos saberes anatomoclínico e higiênico, construiu um fundo de evidências compartilhado por todos. Mais que o diagnóstico sobre a patologia brasileira, as regras que deveriam produzi-lo e validá-lo, formavam a base, o pressuposto que tornava possível a confrontação, o diálogo, a concorrência e mesmo o conflito entre os médicos socializados nesses saberes. Nesse sentido, a Academia de Medicina foi construída como um espaço relativamente autônomo, diferenciando-se de outras arenas mais contenciosas no ambiente sociocultural do Império. Nesse microcosmo não isento de relações de força, hierarquias e concentração de poder, o triunfo de uma opinião deveria corresponder ao convencimento fundado em argumentos, demonstrações e refutações de acordo com as regras epistêmicas da Anatomoclínica e da Topografia Médica, que seguiam procedimentos de validade universal. $\mathrm{O}$ respeito a essas regras metodológicas diferenciavam o debate médico das querelas do mundo político e leigo, em geral, onde as divergências inconciliáveis - acreditava-se - resultariam do caráter interessado, portanto parcial e retórico, das opiniões emitidas. Tal percepção da política como lugar do irracional, em oposição à administração centralizadora, voltada à instituição da sociedade e dinamização da ordem institucional, não singularizava a elite médica. Ela permeou a ideologia da burocracia estatal, durante todo o período imperial. Para essa continuidade, contribuíram a unidade dos quadros burocráticos e o horizonte mental da elite conservadora centrado no modelo de monarquia administrativa, também importado da França. ${ }^{29}$

29 Sobre o tema, ver Carvalho, José Murilo de: A construção da ordem. A elite política imperial, Relume Dumará, Rio de Janeiro, 1996. pág. 56 e Mattos, Ilmar R. de: O tempo saquarema, HUCITEC, São Paulo, 1990, pág. 181. 
Da mesma forma que o médico higienista procurava modificar a postura física, intelectual, moral, sexual e social da família patriarcal, o próprio projeto profissional dos médicos, formulado de acordo com o figurino europeu, era por sua vez confrontado com a prática clientelista imperante, onde uma ética de favores se opunha à ideologia profissional. Dessa maneira, é preciso descrer da suposta autonomia que a literatura histórica tem atribuído às elites médicas na condução das políticas voltadas à saúde pública, formação profissional e controle do exercício da prática médica no período imperial. Não só a Academia de Medicina como também os grupos que se organizavam em torno de sociedades e periódicos médicos lutavam para impor uma ética profissional onde a autoridade científica, baseada na credibilidade e capacitação técnica auferidas pelos pares, se opunha aos mecanismos discricionários de distribuição de cargos públicos como sinecuras e prebendas aos apadrinhados da hora, o que caracterizava a sociabilidade clientelista comandada pela classe senhorial dominante. Como procuramos argumentar, a criação do espaço institucional da Academia de Medicina, no interior da ordem monárquica, marca ao mesmo tempo ruptura e complementaridade com toda tradição médica européia, bem como sujeição das observações e registros médicos feitos por viajantes naturalistas, cirurgiões-barbeiros e boticários ao protocolo anatomoclínico. A participação na Academia Imperial de Medicina supunha critérios meritocráticos. Os debates científicos no interior do campo médico eram baseados não no status social, ou na honra, medida pela inscrição dos médicos na ordem senhorial, e sim no pertencimento a uma corporação científica. Portanto, não era a titularidade nobiliárquica que credenciava a opinião ou testemunho, mas sim a habilidade em atuar de acordo com as regras científicas consagradas nesse microcosmo. 